\title{
FABRICATION OF MIXED HALIDE PEROVSKITE FILMS BY THERMAL CO- EVAPORATION
}

\author{
Onur Yllmaz \\ Department of Micro and Nanotechnology, Middle East Technical University, 06800, Ankara, Turkey, syerci@metu.edu.tr \\ (iD https://orcid.org/ 0000-0002-9685-1293) \\ Selçuk YERCi*
}

Department of Micro and Nanotechnology, Department of Electrical and Electronics Engineering, Center for Solar Energy Research and Applications, Middle East Technical University, 06800,Ankara, Turkey, syerci@metu.edu.tr

(iD https://orcid.org/0000-0003-0599-588X)

Received: 21.04.2019, Accepted: 10.06.2019

Research Article

*Corresponding author

DOI: $10.22531 /$ muglajsci.556597

\begin{abstract}
Thermal co-evaporation is a versatile method to fabricate highly uniform, large area and pin-hole free perovskite films for solar cells. In this study, perovskite films ( $\left.M A P b I_{3-x} B r_{x}\right)$ were fabricated entirely by thermal co-evaporation in the full range $(0 \leq x \leq 3)$ with different $B r / I$ ratio for the first time. Films were characterized optically and structurally using photoluminescence and UV-Vis spectroscopy, X-ray diffraction and scanning electron microscopy. This work presents capability of thermal co-evaporation to fabricate highly-uniform perovskite films at the desired band gaps. $\mathrm{MAPbI}_{2} \mathrm{Br}$ film, developed in this study, exhibits no Stokes shift, and therefore is particularly suitable in achieving high efficiency perovskite/silicon tandem solar cells.
\end{abstract}

Keywords: Band gap tuning, thermal co-evaporation, perovskite

\section{KARIŞIK HALOJENLİ PEROVSKIT FÍLMLERİN TERMAL EŞ-BUHARLAŞTIRMA YÖNTEMİ İLE ÜRETILMESİ}

\section{Özet}

Perovskit tabakalarının termal eș-buharlaștırma yöntemi ile üretilmeleri güneș hücrelerinde kullanılmak üzere geniș alana sahip, delik

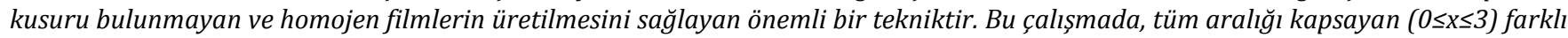
$\mathrm{Br} / \mathrm{I}$ oranına dolayısı ile farklı bant aralıklarına sahip $\mathrm{MAPbI}_{3-\mathrm{x}} \mathrm{Br}_{\mathrm{x}}$ perovskit tabakalar eş-buharlaştırma yöntemi ile ilk kez üretilmişlerdir. Geliştirilen filmlerin optik ve yapısal analizleri fotolüminesans, UV-Vis spektrometresi, X-ışını kırınımı ve taramalı elektron mikroskobu ile yapılmıştır. Bu çalışma termal eş-buharlaştırma tekniği ile farklı bant genişliğine sahip homojen perovskit tabakaların elde edilmesinin mümkün olduğunu göstermektedir. Bu çalıșmada geliştirilen Stokes kaymasına sahip olmadığı gözlemlenen $\mathrm{MAPbI}_{2} \mathrm{Br}$ perovskit filmi, özellikle yüksek verimli perovskit/silisyum çok eklemli güneş hücrelerinin elde edilebilmesi için önemlidir.

Anahtar Kelimeler: Bant aralığı ayarlanabilirliği, termal eş-buharlaştırma, perovskit

Cite

Yılmaz, O., Yerci, S., (2019). “Fabrication of Mixed Halide Perovskite Films By Thermal Co-Evaporation”, Mugla Journal of Science and Technology, 5(2), 68-72.

\section{Introduction}

Since the pioneer work of Kojima et al. in 2009 [1], organicinorganic halide perovskites have been intensively studied, and reached a certified power conversion efficiency value of $23.7 \%$ in 2019 [2]. Among their numerous advantages such as broad absorption [3], long charge diffusion length, high photovoltaic performance and low-cost, the large degree of structural diversity is one of the most important property of $\mathrm{ABX}_{3}$ perovskite films $(A=$ organic cation, $B=$ divalent metal, and $\mathrm{X}=$ halide) [4-6]. Thus, it is possible to tune the band gap of perovskite by altering the $\mathrm{A}, \mathrm{B}$ or $\mathrm{X}$ atoms and/or using multiple cations or anions [7].

Band gap tuning of perovskite films have been widely explored using different fabrication techniques in the literature. In one of the early examples of band gap tuning studies, the single step solution method was used in the fabrication by stoichiometric mixing of $\mathrm{CH}_{3} \mathrm{NH}_{3} \mathrm{PbI}_{3}$ (or simply $\mathrm{MAPbI}_{3}$, which stands for methylamine lead iodide) and $\mathrm{MAPbBr}_{3}$ solutions, and it was concluded that $\mathrm{MAPb}\left(\mathrm{I}_{1-\mathrm{x}} \mathrm{Br}_{\mathrm{x}}\right)_{3}$ film at $\mathrm{x}=0.2$ has the enhanced power conversion efficiency and the stability [8]. Using the same deposition method, the importance of the compositional homogeneity of mixed halide perovskites was addressed in a 
different study [9]. Band gap tuning of mixed halide perovskites was also investigated using the sequential method. $1 \mathrm{M} \mathrm{PbI}_{2}$ solution in DMF was applied by spin coating and the $\mathrm{PbI}_{2}$ films were immersed in mixed solutions of MAI and MABr with different volume ratios. This method demonstrated that dipping time as well as the concentrations of the halide solutions has a major impact on the band gap and the composition of the perovskite films [10].

Along with these solution methods, co-evaporation technique is an important alternative for perovskite deposition. It is known that the vacuum depositions are advantageous to fabricate large area, highly uniform and smooth films [11]. Additionally, it is possible to coat perovskite films with a targeted thickness even on relatively rough surfaces [12-14]. Co-evaporation technique was also used to tune the band gap of mixed bromide iodide lead perovskites $\mathrm{MAPb}\left(\mathrm{I}_{1-\mathrm{x}} \mathrm{Br}_{\mathrm{x}}\right)_{3}\left(0_{-} \mathrm{x}<0.67\right)$ thin films using $\mathrm{MAI}, \mathrm{PbI}_{2}$ and $\mathrm{PbBr}_{2}$ precursors. The $\mathrm{Br}$ concentration was adjusted by controlling the $\mathrm{PbBr}_{2}$ deposition rate (i.e. controlling the temperature of the $\mathrm{PbBr}_{2}$ crucible) while the deposition rates of the $\mathrm{PbI}_{2}$ and MAI were kept same during the deposition [15].

In this work, the structural, morphological and optical properties of thermally co-evaporated $\mathrm{MAPbI}_{3-\mathrm{x}} \mathrm{Br}_{\mathrm{x}}$ films with various $\mathrm{Br} / \mathrm{I}$ ratios in the full range ( $\mathrm{x}$ is ranging from 0 to 3 ) were studied systematically for the first time. The nominal bromide content of the perovskite thin films were set beforehand as $x$ equals to $0,1,1.33,2$ and 3 in the notation of $\mathrm{MAPbI}_{3-\mathrm{x}} \mathrm{Br}_{\mathrm{x}}$. The chemical reaction formulas of the depositions can be described by the following equations (1-5).

$$
\begin{aligned}
& \mathrm{x}=0: \mathrm{MAI}+\mathrm{PbI}_{2} \rightarrow \mathrm{MAPbI}_{3} \\
& \mathrm{x}=1: 2 \mathrm{MAI}+\mathrm{PbI}_{2}+\mathrm{PbBr}_{2} \rightarrow \mathrm{MAPbI}_{2} \mathrm{Br} \\
& \mathrm{x}=1.33: 3 \mathrm{MAI}+\mathrm{PbI}_{2}+2 \mathrm{PbBr}_{2} \rightarrow \mathrm{MAPbI}_{1.67 \mathrm{Br}_{1} .33} \\
& \mathrm{x}=2: 2 \mathrm{MABr}+\mathrm{PbI}_{2}+\mathrm{PbBr}_{2} \rightarrow \mathrm{MAPbIBr}_{2} \\
& \mathrm{x}=3: \mathrm{MABr}+\mathrm{PbBr}_{2} \rightarrow \mathrm{MAPbBr}_{3}
\end{aligned}
$$

The results clearly demonstrate the band gap widening and lattice space decreasing with increasing $\mathrm{Br}^{-}$concentration. $\mathrm{MAPbI}_{2} \mathrm{Br}$ film with a band gap of $1.65 \mathrm{eV}$, which is suitable for tandem solar cells was fabricated with no Stokes shift determined from PL and UV-Vis spectroscopies.

\section{Materials and Methods}

Unless otherwise stated, all chemicals were purchased from commercial sources and used without further purification. Perovskite depositions were made in ambient atmosphere (30\% relative humidity $[\mathrm{RH}]$ and $26-30^{\circ} \mathrm{C}$ ) on glass substrates. Lead iodide $\left(\mathrm{PbI}_{2}, 99.999 \%\right)$ and lead bromide $\left(\mathrm{PbBr}_{2}\right.$, 99.999\%) powders were obtained from Sigma-Aldrich. Surface morphology of the perovskite films were investigated by Quanta 400F Scanning Electron Microscope. Structural analyses were conducted at room temperature in $2 \Theta$ scan range

\begin{tabular}{|c|c|c|c|c|c|c|c|c|c|c|}
\hline \multirow[t]{2}{*}{ Ratio } & \multicolumn{3}{|c|}{ Source 1} & \multicolumn{3}{|c|}{ Source 2} & \multicolumn{3}{|c|}{ Source 3} & \multirow{2}{*}{$\begin{array}{c}\text { Diffusion } \\
\text { valve } \\
\text { opening }\end{array}$} \\
\hline & Material & $\begin{array}{c}\text { Temp. } \\
\left({ }^{\circ} \mathrm{C}\right)\end{array}$ & $\begin{array}{l}\text { Rate } \\
(\AA / \mathrm{s})\end{array}$ & Material & $\begin{array}{c}\text { Temp. } \\
\left({ }^{\circ} \mathrm{C}\right)\end{array}$ & $\begin{array}{c}\text { Rate } \\
(\AA / \mathrm{s})\end{array}$ & Material & $\begin{array}{l}\text { Temp } \\
.\left({ }^{\circ} \mathrm{C}\right)\end{array}$ & $\begin{array}{l}\text { Rate } \\
(\AA / s)\end{array}$ & \\
\hline$x=0$ & & & - & MAI & 195 & 0.5 & $\mathrm{PbI}_{2}$ & 285 & 0.3 & $24 \%$ \\
\hline
\end{tabular}
of $10^{\circ}-45^{\circ}$ with Rigaku Miniflex X-Ray diffractometer using $\mathrm{Cu}$ $\mathrm{K}_{\alpha}(0.154 \mathrm{~nm})$ radiation. Transmission and reflection spectra Table 1. Fabrication details (temperature of crucibles, deposition rate of source materials and diffusion pump valve opening ratios) of co-evaporated $\mathrm{MAPb}\left(\mathrm{I}_{1-\mathrm{x}} \mathrm{Br}_{\mathrm{x}}\right)_{3}$ films. 


$\begin{array}{ccccccccccc}\mathrm{x}=1 & \mathrm{PbBr}_{2} & 325 & 0.3 & \mathrm{MAI} & 200 & 0.6 & \mathrm{PbI}_{2} & 285 & 0.3 & 20 \% \\ \mathrm{x}=1.33 & \mathrm{PbBr}_{2} & 335 & 0.4 & \mathrm{MAI} & 190 & 0.6 & \mathrm{PbI}_{2} & 280 & 0.2 & 16 \% \\ \mathrm{x}=2 & \mathrm{PbBr}_{2} & 320 & 0.3 & \mathrm{MABr} & 230 & 0.6 & \mathrm{PbI}_{2} & 285 & 0.3 & 16 \% \\ \mathrm{x}=3 & \mathrm{PbBr}_{2} & 320 & 0.3 & \mathrm{MABr} & 230 & 0.5 & - & - & - & 30 \%\end{array}$

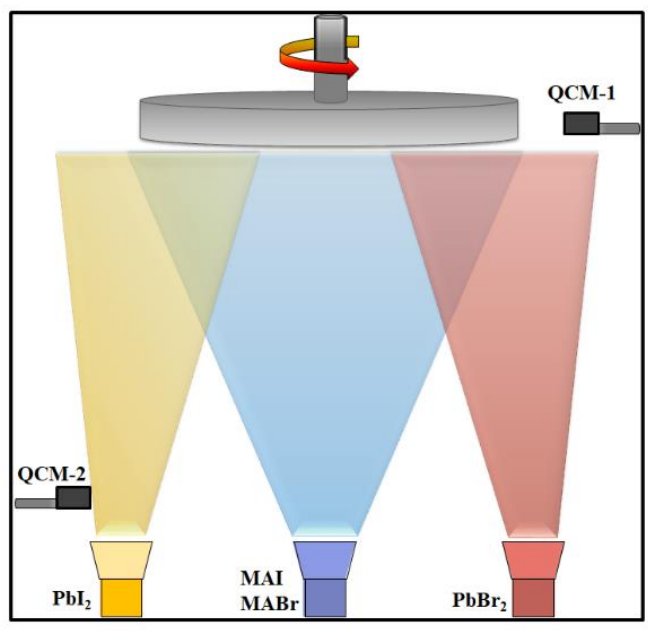

Figure 1. Three-sourced vacuum co-evaporation of perovskite films.

Figure 2 shows the optical images $\mathrm{MAPbI}_{3-\mathrm{x}} \mathrm{Br}_{\mathrm{x}}(0 \leq \mathrm{x} \leq 3)$ films on glass. A color transition from dark brown to orange and yellow with increasing $\mathrm{Br}$ content (i.e. increasing $\mathrm{x}$ in the stoichiometry) indicates the increasing band gap of the perovskite films.



Figure 2. Optical images of evaporated MAPbI3-xBr films (top), color transition of evaporated $\mathrm{MAPbI}_{3-\mathrm{x}} \mathrm{Br}_{\mathrm{x}}$ films (bottom).

\subsection{Structural and morphological characterization}

Figure 3a shows the XRD patterns of $\mathrm{MAPbI}_{3-\mathrm{x}} \mathrm{Br}_{\mathrm{x}}(0 \leq \mathrm{x} \leq 3)$. A systematic change was monitored from the tetragonal structure of $\mathrm{MAPbI}_{3}$ to the cubic structure of $\mathrm{MAPbBr}_{3}[1,8,16$, 17]. Two peaks of $\mathrm{MAPbI}_{3}$ located at $14.15^{\circ}$ and $28.40^{\circ}$ are associated with the (110)t and (220)t crystal planes, respectively. As seen in diffractograms, replacement of I with $\mathrm{Br}$ in $\mathrm{MAPbI}_{3-\mathrm{x}} \mathrm{Br}_{\mathrm{x}}$ film caused the transforming of (110)t peak into (100)c peak, while (220)t peak into (200)c peak. With increasing $\mathrm{Br}$ content, gradual shifts were monitored for peaks diffracted by the (100)c and (200)c planes toward higher $2 \Theta$ degrees due to decreasing lattice spacing with smaller $\mathrm{Br}$ - ions. The average crystallite size of the perovskite films were estimated according to Scherrer's equation using the full width at half maximum (FWHM) values (Figure $3 \mathrm{~b}$ ) of the peaks originated from (110)t and (100)c planes [18-20]. Fractional differences were observed in grain sizes resulting from the inherent local variations of halides in lattice positions. They were calculated as $29.53 \mathrm{~nm}, 26.97 \mathrm{~nm}, 18.57 \mathrm{~nm}, 24.26 \mathrm{~nm}$, and $25.74 \mathrm{~nm}$ in the order of increasing Br content.

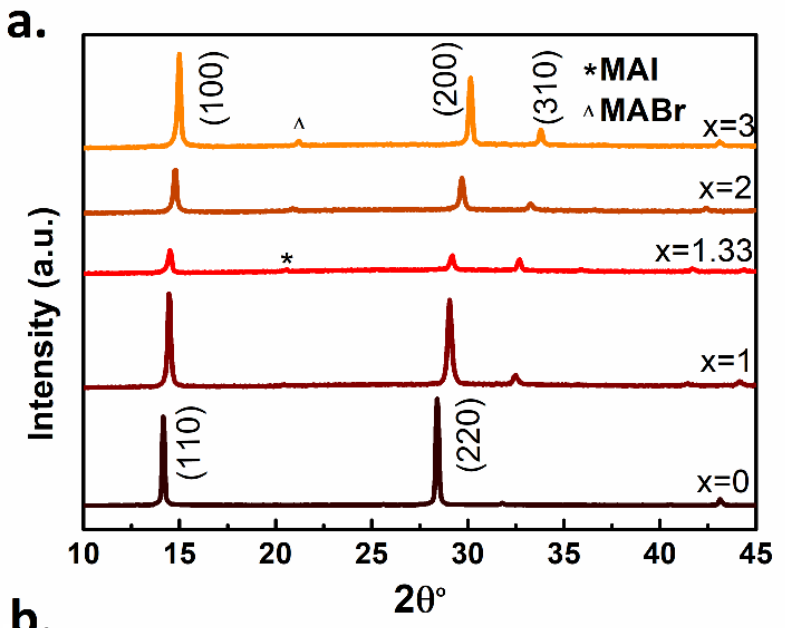

b.

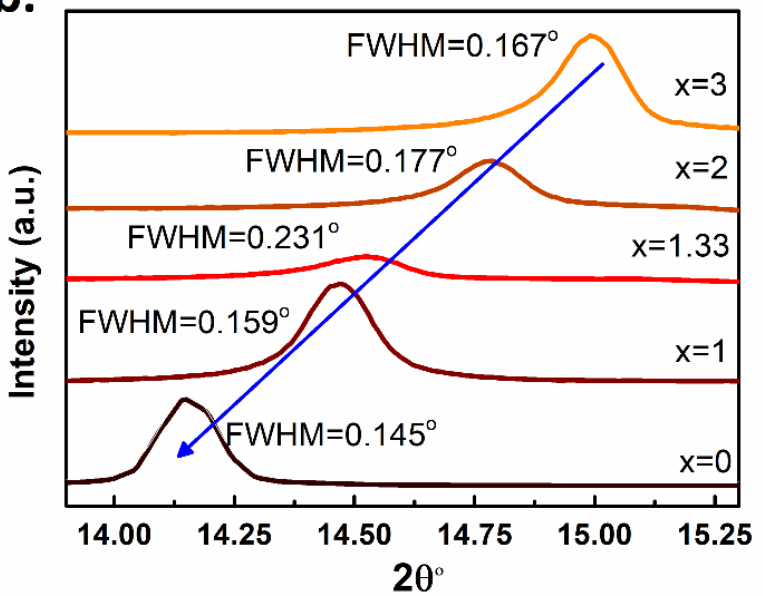

Figure 3. (a) XRD patterns of perovskite films (b) Detailed scans of the (110)t and (100)c crystal orientations. 


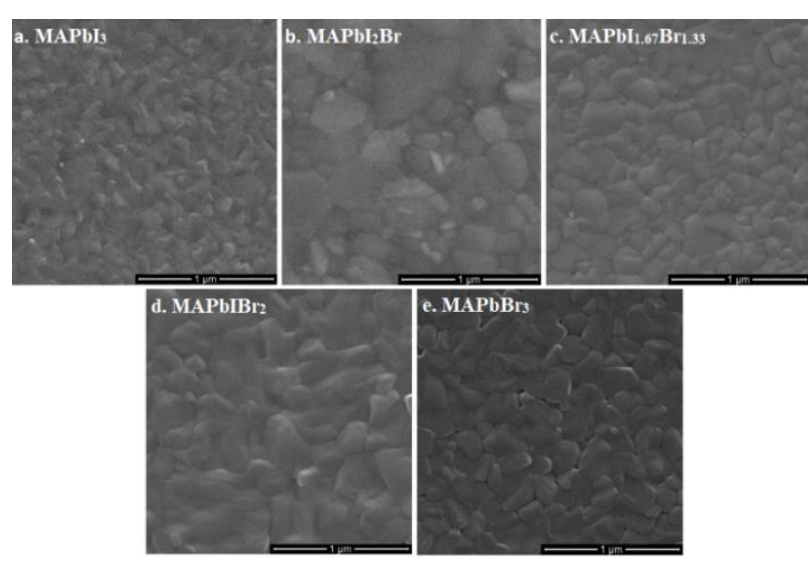

Figure 4. SEM images of co-evaporated perovskite films (a) $\mathrm{MAPbI}_{3}$ (b) MAPbI $2 \mathrm{Br}$ (c) MAPbI $\mathrm{M}_{1.67} \mathrm{Br}_{1.33}$ (d) MAPbIBr 2 and (e) $\mathrm{MAPbBr}_{3}$.

Figure 4 shows the scanning electron microscopy (SEM) images of the co-evaporated perovskite films. Films with all compositions have a complete coverage of glass surfaces, and they are pinhole free and homogeneous. The most apparent difference was observed for the $\mathrm{MAPbI}_{3}$ film which has a preferential crystal orientation of (110)t. Films with $\mathrm{Br}$ incorporation typically have larger crystal grains at the top surface of the films with a maximal for the $\mathrm{MAPbI}_{2} \mathrm{Br}$ film.

\subsection{Optical analysis}

Absorption spectra of co-evaporated perovskite films on glass substrates were recorded to monitor their optical responses. The corresponding gradual shift in the absorption band edges, illustrated in Figure 5a, provides further confirmation that $\mathrm{Br}$ has successfully incorporated to the $\mathrm{MAPbI}_{3-\mathrm{x}} \mathrm{Br}_{\mathrm{x}}(0 \leq \mathrm{x} \leq 3)$ films by the co-evaporation. The absorption onset value shifts systematically from $810 \mathrm{~nm}\left(\mathrm{MAPbI}_{3}\right)$ to $580 \mathrm{~nm}\left(\mathrm{MAPbBr}_{3}\right)$ with increasing MABr content. The optical band gap of $\mathrm{MAPbI}_{3}$. ${ }_{x} B r_{x}$ films were calculated in the range between $1.55 \mathrm{eV}$ and 2.3 $\mathrm{eV}$ using the Tauc plots (Figure $5 \mathrm{~b}$ ), which are consisted with the earlier reports in the literature [8], and demonstrating that band gap of $\mathrm{MAPbI}_{3-\mathrm{x}} \mathrm{Br}_{\mathrm{x}}$ can be controlled by co-evaporation of $\mathrm{MAI} / \mathrm{MABr}, \mathrm{PbI}_{2}$ and $\mathrm{PbBr}_{2}$.

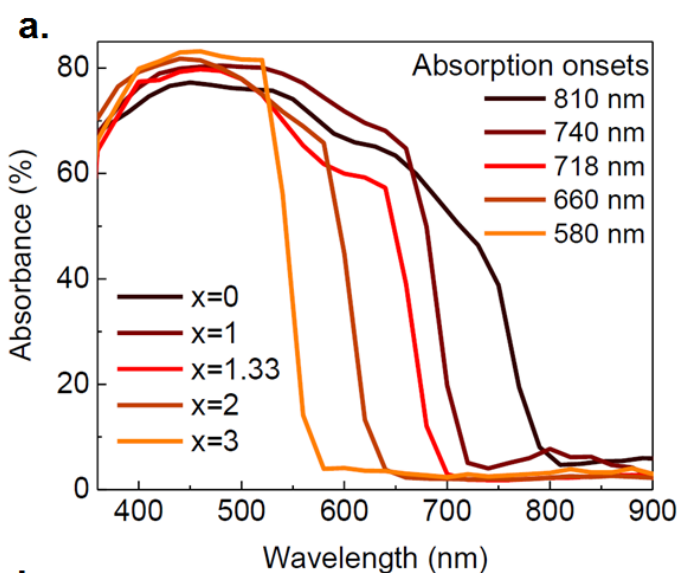

b.

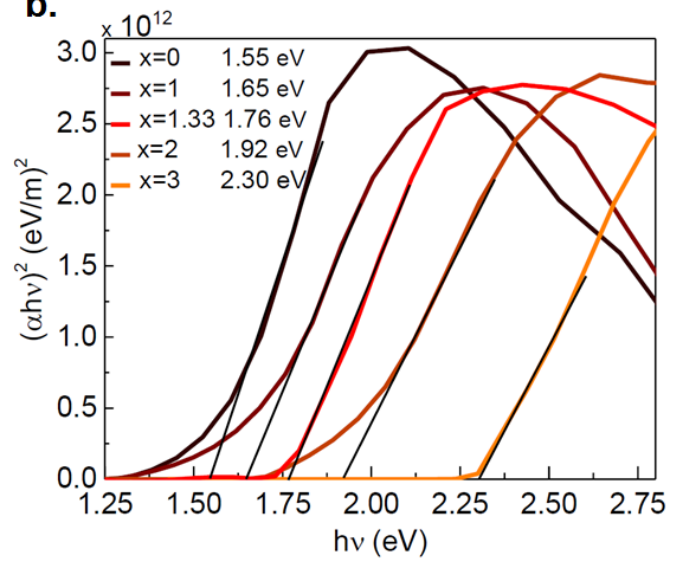

Figure 5. (a) Absorption spectra of perovskite films (b) Tauc plots of perovskite films having different band gap values.

Figure 6 shows the photoluminescence spectra of coevaporated $\mathrm{MAPbI}_{3-\mathrm{x}} \mathrm{Br}_{\mathrm{x}}(0 \leq \mathrm{x} \leq 3)$ films with different $\mathrm{x}$ values. The PL signal peaks at wavelengths located in between $533 \mathrm{~nm}$ and $801 \mathrm{~nm}$ for $\mathrm{x}=0$ and $\mathrm{x}=3$, respectively. A clear blue-shift of the PL peak position with $\mathrm{Br}$ incorporation is observed. Under $532 \mathrm{~nm}$ and $325 \mathrm{~nm}$ excitations, we observed no decomposition (i.e. formation of multiple PL peaks) of the films, indicating films are mostly homogenous in composition.

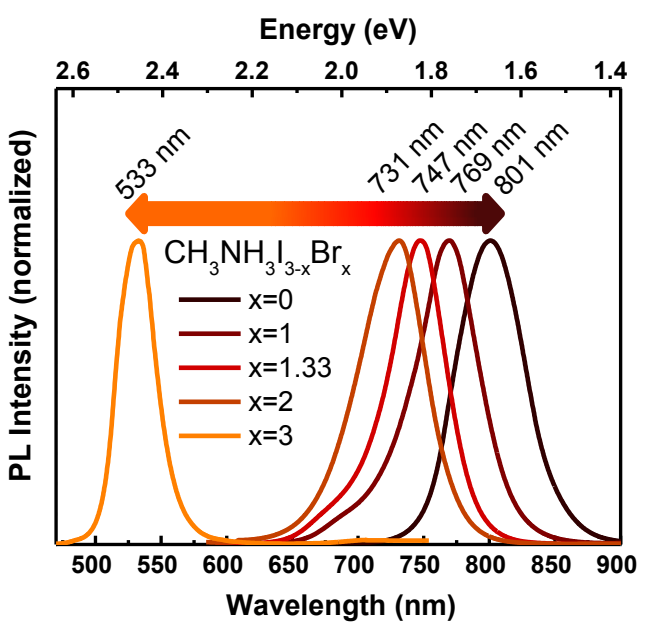

Figure 6. Normalized PL peaks of the $\mathrm{MAPbI}_{3-\mathrm{x}} \mathrm{Br}_{\mathrm{x}}$ films. 
The comparison of the optical band gap values obtained from the Tauc-plots and the PL peaks are given in Figure 7. As shown in the figure, band gap values differ nearly $\sim 0.1 \mathrm{eV}$ and $\sim 0.2 \mathrm{eV}$ for the $\mathrm{MAPbI}_{1.67} \mathrm{Br}_{1.33}$ and $\mathrm{MAPbIBr}_{2}$, respectively. These discrepancies can be attributed to the halide migration and/or the lattice relaxation [9]. On the other hand, the $\mathrm{MAPbI}_{2} \mathrm{Br}$ mixed halide perovskite showed a very small shift in its optical band gap values which were calculated as $1.65 \mathrm{eV}$ from the Tauc plot and $1.61 \mathrm{eV}$ from its PL peak. This small difference indicates the co-evaporation of $\mathrm{PbI}_{2}, \mathrm{PbBr}_{2}$ and MAI resulted in a single phase perovskite film with a band gap suitable for tandem solar cell applications.



Figure 7. Comparison of the band gap values of $\mathrm{MAPbI}_{3-\mathrm{x}} \mathrm{Br}_{\mathrm{x}}(0$ $\leq \mathrm{x} \leq 3$ ) films.

\section{Conclusion}

Co-evaporation of $\mathrm{PbI}_{2}, \mathrm{PbBr}_{2}$ and $\mathrm{MAI} / \mathrm{MABr}$ allowed us to study the effect of $\mathrm{Br} / \mathrm{I}$ ratio on morphological and optical properties of perovskite layers more systematically and reliably. Five sets of pin-hole free and homogenous $\mathrm{MAPbI}_{3-\mathrm{x}} \mathrm{Br}_{\mathrm{x}}$ $(0 \leq \mathrm{x} \leq 3)$ perovskite films with different shades of brown and orange colors were successfully fabricated on glass substrates. Gradual shifts of the XRD peaks toward higher $2 \theta^{\circ}$ observed with the increasing amount of relatively small $\mathrm{Br}^{-}$ions. Our results showed that, it is possible to tune the band of the mixed halide perovskite in the full range of $\mathrm{Br} / \mathrm{I}$ ratio. We have achieved to fabricate $\mathrm{MAPbI}_{2} \mathrm{Br}$ mixed halide perovskite with a band gap of $1.65 \mathrm{eV}$ and negligibly-small Stokes shift, suitable for perovskite/silicon tandem solar cells.

\section{Acknowledgment}

This work was supported by the Scientific and Technological Research Council of Turkey (TÜBİTAK), Grant No: 114F306. S.Y. would like to offer his special thanks to Wiria Soltanpoor for his help in fabrication and characterization of perovskite films.

\section{References}

[1] Kojima, A., Teshima, K., Shirai, Y. and Miyasaka, T., "Organometal Halide Perovskites as Visible-Light Sensitizers for Photovoltaic Cells", Journal of the American Chemical Society, 131(17), 6050-6051, 2009.

[2] https://www.nrel.gov/pv/cell-efficiency.html

[3] Kim, H.S., Lee, C.R., Im, J.H., Lee, K.B., Moehl, T., Marchioro, A., Moon, S.J., Humphry-Baker, R., Yum, J.H., Moser, J.E. Grätzel, M. and Park, N.G., "Lead Iodide Perovskite Sentisized All-Solid-State Submicron Thin Film Mesoscopic
Solar Cell with Efficiency Exceeding 9\%", Scientific Reports, 2(591), 1-7, 2012.

[4] Chen, W., Wu, Y., Yue, Y., Liu, J., Zhang, W., Yang, X., Chen, H., Bi, E., Ashraful, I., Grätzel, M. and Han, L., "Efficient and Stable Large-Area Solar Cells with Inorganic Charge Extraction Layers", Science, 350, 944-948, 2015.

[5] Shi, D., Adinolfi, V., Comin, R., Yuan, M., Alarousu, E., Buin, A., Chen, Y., Hoogland, S., Rothenberger, A., Katsiev, K., Losovyj, Y., Zhang, X., Dowben, P., Mohammed, O., Sargent E. and Bakr O., "Low Trap-State Density and Long Carrier Diffusion in Organolead Trihalide Perovskite Single Crystals", Science, 347, 519-522, 2015.

[6] Cao, K., Li, H., Liu, S.S., Cui, J., Shen Y. and Wang, M., "MAPbI $3-\mathrm{BBr}$ Mixed Halide Perovskites for Fully Printable Mesoscopic Solar Cells with Enhanced Efficiency and Less Hysteresis", Nanoscale, 8, 8839-8846, 2016.

[7] Sahli, F., Werner, J., Kamino, B.A., Brauninger, M., Monnard, R., Paviet-Salomon, B., Barraud, L., Ding, L., Leon, J.J.D., Sacchetto, D., Cattaneo, G., Despeisse, M., Boccard, M., Nicolay, S., Jeangros, Q., Niesen, B. and Ballif, C. "Fully Textured Monolithic Perovskite/Silicon Tandem Solar Cells with 25.2\% Power Conversion Efficiency", Nature Materials, 17, 820-826, 2018.

[8] Noh, J.H., Im, S.H., Heo, J.H., Mandal, T.N. and Seok, S.I., "Chemical Management for Colorful, Efficient, and Stable Inorganic-Organic Hybrid Nanostructured Solar Cells", Nano Letters, 13, 1764-1769, 2013.

[9] Sadhanala, A., Deschler, F., Thomas, T.H., Dutton, S.E., Goedel, K.C., Hanusch, F.C., Lai, M.L. Steiner, U., Bein, T. Docampo, P., Cahen, D. and Friend, R.H., "Preparation of Single-Phase Films of $\left.\mathrm{CH}_{3} \mathrm{NH}_{3} \mathrm{~Pb}_{\left(\mathrm{I}_{1}-\mathrm{BBr}\right.}\right)_{3}$ with Sharp Optical Band Edges", The Journal of Physical Chemistry Letters, 5, 2501-2505, 2014.

[10] Kulkarni, S.A., Baikie, T., Boix, P.P., Yantara, N., Mathews N. and Mhaisalkar, S., "Band-Gap Tuning of Lead Halide Perovskites Using a Sequential Deposition Process", Journal of Materials Chemistry A, 2, 9221-9225, 2014.

[11] Liang G., Lan H., Fan, P., Lan, C., Zheng, Z., Peng, H. and Luo, J., "Highly Uniform Large-Area $\left(100 \mathrm{~cm}^{2}\right)$ Perovskite $\mathrm{CH}_{3} \mathrm{NH}_{3} \mathrm{PbI}_{3}$ Thin-Films Prepared by Single-Source Thermal Evaporation", Coatings, 8, 256(1-11), 2018.

[12] Liu, M., Johnston, M.B. and Snaith, H.J., "Efficient Planar Heterojunction Perovskite Solar Cells by Vapour Deposition", Nature, 501, 395-398, 2013.

[13] McMeekin, D.P., Sadoughi, G., Rehman, W., Eperon, G.E., Saliba, M., Hörantner, M.T., Haghighirad, A., Sakai, N., Korte, L., Rech, B., Johnston, M.B., Herz, L.M. and Snaith, H.J., "A Mixed-Cation Lead Mixed-Halide Perovskite Absorber for Tandem Solar Cells", Science, 351, 151-155, 2016.

[14] Eperon, G. E., Leijtens, T., Bush, K.A., Prasanna, R., Green, T., Wang, J.T.-W., McMeekin, D.P., Volonakis, G., Milot, R.L., May, R., Palmstrom, A., Slotcavage, D.J, Belisle, R.A., Patel, J.B., Parrott, E.S., Sutton, R.J., Ma, W., Moghadam, F., Conings, B., Babayigit, A., Boyen, H.-G., Bent, S., Giustino, F., Herz, L.M., Johnston, M.B., McGehee, M.D. and Snaith, H.J., "Perovskite-Perovskite Tandem Photovoltaics with Optimized Band Gaps", Science, 354, 861-865, 2016.

[15] Zhou, X., Ye, W., Li, X., Zheng, W., Lin, R., Huang, F. and Zhong, D., "Band Alignment of MAPb $\left(\mathrm{I}_{1-x} \mathrm{Br}_{\mathrm{x}}\right)_{3}$ Thin Films by Vacuum Deposition", Applied Physics Letters, 109, 233906(1-4), 2016.

[16] Im, J.-H., Lee, C.-R., Lee, J.-W, Park, S.-W. and Park, N.-G. "6.5\% Efficient Perovskite Quantum-Dot-Sensitized Solar Cell”, Nanoscale, 3, 4088-4093, 2011. 
[17] Baikie, T., Fang, Y., Kadro, J.M., Schreyer, M., Wei, F., Mhaisalkar, S.G., Gratzel, M. and White, T.J., "Synthesis and Crystal Chemistry of the Hybrid Perovskite $\left(\mathrm{CH}_{3} \mathrm{NH}_{3}\right)_{\mathrm{PbI}_{3}}$ for Solid-State Sensitised Solar Cell Applications", Journal of Materials Chemistry A, 1, 5628-5641, 2013.

[18] Hu, Y., Schlipf, J., Wussler, M., Petrus, M.L., Jaegermann, W., Bein, T. Müller-Buschbaum, P. and Docampo, P., "Hybrid Perovskite/Perovskite Heterojunction Solar Cells" ACS Nano, 10, 5999-6007, 2016.

[19] Patterson, A.L., "The Scherrer Formula for X-Ray Particle Size Determination", Physical Review, 56, 978-982, 1939.

[20] Wang, K., Lin, Z., Ma, J., Liu, Z., Zhou, L., Du, J., Chen, D., Zhang, C., Chang, J. and Hao, Y., "High-Performance SimpleStructured Planar Heterojunction Perovskite Solar Cells Achieved by Precursor Optimization", ACS Omega, 2, 6250-6258, 2017. 